\title{
Uranium-Series Disequilibria in the Groundwater of the Shihongtan Sandstone-Hosted Uranium Deposit, NW China
}

\author{
Xinjian Peng ${ }^{1,2}$, Maozhong Min ${ }^{1}$, Haiming Qiao ${ }^{3}$, Jinping Wang ${ }^{3}$ and Mostafa Fayek ${ }^{4, *}$ \\ Received: 7 October 2015; Accepted: 23 December 2015; Published: 30 December 2015 \\ Academic Editor: Karen Hudson-Edwards \\ 1 Department of Earth Sciences, State Key Laboratory of Mineral Deposit research, Nanjing University, \\ Nanjing 210093, China; p_xj@263.net (X.P.); mzmin888888@163.com (M.M.) \\ 2 Bureau of Geology, China National Nuclear Corporation, Beijing 100013, China \\ 3 Northwest Institute of Uranium Geology, China National Nuclear Corporation, Xianyang 712000, China; \\ qhm163@yahoo.com.cn (H.Q.); cnnc203@sina.com (J.W.) \\ 4 Department of Geological Science, University of Manitoba, Winnipeg, MB R3T 2N2, Canada \\ * Correspondence: Mostafa.Fayek@umanitoba.ca; Tel.: +1-865-696-2785
}

\begin{abstract}
Uranium (U) concentration and the activities of ${ }^{238} \mathrm{U},{ }^{234} \mathrm{U}$, and ${ }^{230} \mathrm{Th}$ were determined for groundwaters, spring waters, and lake water collected from the Shihongtan sandstone-hosted $\mathrm{U}$ ore district and in the surrounding area, NW China. The results show that the groundwaters from the oxidizing aquifer with high dissolved oxygen concentration $\left(\mathrm{O}_{2}\right)$ and oxidation-reduction potential (Eh) are enriched in $U$. The high $U$ concentration of groundwaters may be due to the interaction between these oxidizing groundwaters and $U$ ore bodies, which would result in $U$ that is not in secular equilibrium. Uranium is re-precipitated as uraninite on weathered surfaces and organic material, forming localized ore bodies in the sandstone-hosted aquifer. The ${ }^{234} \mathrm{U} /{ }^{238} \mathrm{U},{ }^{230} \mathrm{Th} /{ }^{234} \mathrm{U}$, and ${ }^{230} \mathrm{Th} /{ }^{238} \mathrm{U}$ activity ratios (ARs) for most water samples show obvious deviations from secular equilibrium (0.27-2.86), indicating the presence of water-rock/ore interactions during the last $1.7 \mathrm{Ma}$ and probably longer. The ${ }^{234} \mathrm{U} /{ }^{238} \mathrm{U}$ AR generally increases with decreasing $\mathrm{U}$ concentrations in the groundwaters, suggesting that mixing of two water sources may occur in the aquifer. This is consistent with the fact that most of the $\mathrm{U}$ ore bodies in the deposit have a tabular shape originati from mixing between a relatively saline fluid and a more rapidly flowing U-bearing meteoric water.
\end{abstract}

Keywords: sandstone-hosted uranium deposit; groundwater; U-series disequilibrium; China

\section{Introduction}

Bulk dissolution of most rocks $>1$ Ma that have not experienced recent water-rock interactions yield dissolved uranium (U) with a ${ }^{234} \mathrm{U} /{ }^{238} \mathrm{U}$ activity ratio (AR) near 1 [1-7]. However, ${ }^{234} \mathrm{U}$ enters solutions preferentially as the results of $\alpha$-recoil damage of crystal-lattice sites containing ${ }^{234} \mathrm{U}$, radiation-induced oxidation of ${ }^{234} \mathrm{U}$, and preferential leaching of ${ }^{234} \mathrm{U}$ from the $\alpha$-recoil tracks [8]. Thus, natural waters typically are enriched in ${ }^{234} U$ with ${ }^{234} U /{ }^{238} U$ AR between 1 and $10[9,10]$. The $\mathrm{U}$ concentration and ${ }^{234} \mathrm{U} /{ }^{238} \mathrm{U}$ AR along a groundwater flow path depends on the balance between factors such as $\mathrm{pH}$, oxidation potential, partial pressure of $\mathrm{CO}_{2}$, mineral dissolution, aquifer rock composition, flow-path length, and ground-water flux [3].

Uranium-series disequilibrium data from groundwater can give information concerning recent migration history of radionuclide and geochemical conditions associated with water-rock interaction [11,12]. From a dating point of view, the method covers the time period extending back over the last 1.7 million years, which is particularly interesting for paleohydrogeological research $[13,14]$. 
The use of U-Th disequilibrium to understand water-rock interactions and groundwater flow have been previously reported [3,13,15-18].

Interstratified sandstone-hosted $U$ deposits were found in Yili Basin, Xinjiang, North Western China 15 years ago. These $U$ deposits are economically viable and are an important source of $U$ in China. The deposits are hosted by flat-lying porous sandstones. The Shihongtan $U$ deposit is the largest in scale and tonnage and was formed from the interaction between uraniferous oxidizing groundwaters and reducing sulphide rich horizons in the sandstone. The groundwater moves along the interface between the Jurassic porous sandstones and impermeable mudstone strata. Uranium-series disequilibria in groundwater of the sandstone-hosted $U$ deposit occurs as a result of water-rock interactions, and it provides useful information on the dissolution-precipitation and mineralization of $U$ during the past 1.7 Ma. The solubility of $U$ in the groundwater is very sensitive to changes in redox conditions. The position of the reducing barrier in an active aquifer is important when prospecting for this type of $U$ deposit as well because ${ }^{234} U /{ }^{238} \mathrm{U}$ can be used as a natural groundwater tracer $[15,19]$.

The objective of this study is to use U-series disequilibria and $U$ concentrations in groundwaters from the Shihongtan $U$ ore district to: (1) investigate the relationship between $U$ and dissolved oxygen $\left(\mathrm{O}_{2}\right)$ concentrations; (2) oxidation-reduction potential (Eh) in the groundwaters; and (3) the presence of water-rock interaction and mixing between a relatively stagnant saline fluid and a more rapidly flowing U-bearing meteoric water.

\section{Study Area}

The Shihongtan U deposit occurs within the Tuha Basin, Xinjiang, northwestern China (Figure 1A). The basin is an elongated, closed, continental basin and has an east-westerly trend. It hosts several large oil and natural gas reservoirs, as well as coalfields, and therefore is economically important. Basement rocks of the basin are Proterozoic metasediment, Carboniferous intermediate-acidic volcanic rocks and Hercynian granite, and cap rocks are Lower Permian and Triassic detrital rocks, Jurassic conglomerate, sandstone, shale and coal, Cretaceous and Tertiary red continental detrital rocks, and Quaternary. The oldest rocks exposed in this region are the Middle Proterozoic quartzite, marble, and carbonaceous slates, which are unconformably overlain by the Lower Palaeozoic conglomerate, sandstone, shale, and limestone. The Carboniferous intermediate-acidic volcanic, volcaniclastic rocks rest unconformably over the Lower Palaeozoic units, and are in turn unconformably overlain by sandstone and shale of the Permian and Upper Triassic Xiaoquangou group. The Lower to Middle Jurassic Shuixigou Group, consisting of conglomerate, sandstone, shale, and coal beds, occurs on top of these Triassic rocks. Tertiary red conglomerates, sandstone, and shale, unconformably overlying the Lower to Middle Jurassic Shuixigou Group, themselves are unconformably overlain by the gravel, sand, and clay of the Quaternary. Several northwest-, northeast- and less commonly eastwest-trending regional faults occur in both ore districts. The detailed geology of the Shihongtan U deposit was described in the literature [20-22].

The deposit is located in the southwestern limb of the Tuha Basin regional ground-water flow system (Figure 1B). The sandstones that host the deposits are part of the Lower-Middle Jurassic Shuixigou Group. The sandstone typically contains $40 \%-55 \%$ quartz, $20 \%-35 \%$ lithics, $8 \%-15 \%$ feldspar and $2 \%-3 \%$ carbonaceous debris consisting of tuff, andesite, granite, rhyolite quartzite, sandstone, siltstone, and slate, with small detrital grains of biotite, muscovite, tourmaline, apatite, zircon, magnetite, and ilmenite. Sandstone associated with $\mathrm{U}$ mineralization is gray to dark gray, medium- to coarse-grained, and contains carbonaceous debris [20-22]. It is interpreted to be alluvial fan-braided river facies, consisting of equal amounts of quartz, feldspar, and rock fragments. Ore bodies are mainly tabular, and lens shaped. Ores are gray, dark gray or black in color, resulting from the occurrence of $U$ minerals, iron sulfides, and carbonaceous debris. Ore-stage metallic minerals are uraninite, coffinite, pyrite, marcasite, sphalerite, galena, and hematite. ${ }^{234} \mathrm{U} /{ }^{238} \mathrm{U}$ and ${ }^{230} \mathrm{Th} /{ }^{234} \mathrm{U}$ activity ratios of the ore and host sandstone were measured [23]. 
Water flows through this porous rock via a network of fractures from the outcrop region in the southwest, toward Aiting Lake in the northeast (Figure 1). South of the recharge area, the sandstone is conformably overlain by Cretaceous sandstone. The gently dipping $\left(5^{\circ}\right.$ to $\left.10^{\circ}\right)$ contact among the cap rock-strata establishes the aquifer's northern boundary. General groundwater flow directions in the regional Carboniferous volcanic and basin-fill aquifers, shown in Figure 1, illustrate the potential groundwater flow paths for waters discharging in the basin, and are strongly influenced by basin-and-range-style linear mountain ranges and piedmont alluvial fan, as well as by the general decrease in surface elevations from the south to the north. The hydro-stratigraphy of the basin includes many of the units described by the Northwest Institute of Uranium Geology [22]. The Proterozoic and Carboniferous stratigraphic units comprise the lower aquifer. Those units are complexly fractured and the fractures are believed to have enhanced hydraulic connectivity. Much of the Mesozoic stratigraphy forms a regional sandstone aquifer. Jurassic mudstone and coal stratigraphy may locally be aquifers, but generally form barriers and aquitards to groundwater flow. Uppermost Tertiary and Quaternary alluvial basin-fill deposits comprise the regional basin-fill aquifer. Groundwater flow in the regional sandstone and basin-fill aquifers is commonly hydrologically connected throughout much of the southwestern Tuha basin. Most of the recharge for the regional aquifer is from the mountainous regions south of the basin and, partially, from snowmelt water on the Bogeda Mountain in the north of the basin [22]. The Jiaoluotage Mountain range along the southern margin of the basin produces sufficient moisture for groundwater recharge to occur in the basin. The climate across the Tuha basin is arid with a mean annual precipitation of approximately $17 \mathrm{~mm}$. The annual evapotranspiration there, however, is more than $3000 \mathrm{~mm}$. The mean annual temperature is $13.9^{\circ} \mathrm{C}$ and the highest temperature in the summer reaches $50^{\circ} \mathrm{C}$, the highest temperature in China. Given the low precipitation to evapotranspiration ratio, recharge into the aquifer from direct infiltration of rainfall precipitation is small. Discharge of groundwater occurs primarily through natural springs and Lake Aiting. Most of the larger discharge springs emanate from either the Carboniferous intermediate-acidic volcanic and volcaniclastic rocks (Spring 2 or sample 2, Table 1) around the margin of the basin or from Quaternary rocks within the basin (Spring 1 or sample 1). Lake Aiting with an elevation of $-155 \mathrm{~m}$ is the lowest point of elevation in continental China. Water flows through porous sandstones via a network of fractures from the outcrop region in the southwest, toward Aiting Lake in the northeast (Figure 1). The present flow direction of surface water and groundwater in the horizontal plane is from southwest to northeast. The basin is a discharge area for regional groundwater flow. The major and trace element chemistry of the groundwater is reported in Min et al. [22].

Based on source and occurrence, all water samples presented in Table 1 can be divided into three facies, i.e., facies 1 (Spring 1 or sample 1), a representative of fresh near-recharging groundwater which is derived from meteoric precipitation and does not interact with rocks, facies 2 which includes discharging deep groundwater (samples 2) and groundwater runoff (samples 3-18), and facies 3 (Aiting Lake water or sample 19) which is strongly evaporated surface water and discharged groundwater.

\section{Sampling and Analytical Techniques}

From a migration point of view, rainwater falling on the topographic high is assumed to constitute the source of recharge after which water and U-series radionuclides migrate downwards along a series of interstratified oxidized-zone of sandstone strata. The section from the ground surface via boreholes Zk3w4, Zk5w1, Zk5w3, Zk9w5g, Zk9w5, Zk7w2, Zk5-3, Zk7-3, and Zk2-1 defines the central part of the flow system. Water-rock and water-ore interactions along the defined groundwater flow path are expected to affect the U-series disequilibrium signature of the groundwater.

Sampling sites were chosen to cover the Shihongtan ore district. The groundwater samples were collected from 16 sites including, boreholes (samples 3-18) that intersect U ore at the deposit, two springs (samples 1 and 2) that are used for potable water and are located at the margin of the ore district, and one site near Aiting Lake that represents the discharge of groundwater (Figure 1, Table 1). Spring 1 water (sample 1) is used as drinking water by the local inhabitants. The sampling depths 
of the groundwater range from 30 to $345 \mathrm{~m}$. One surface-water sample was also collected from Lake Aiting. The suspended matter in the water samples was separated by filtration through a filter of $0.45 \mu \mathrm{m}$ pore size. The $\mathrm{pH}$ and $\mathrm{Eh}$ of the water were measured at the sampling site.

Polyethylene bottles were used; they were washed successively with dilute acid and distilled water before taking the samples. At each site, $5 \mathrm{~L}$ of water was sampled for analysis, and the samples were acidified with $\mathrm{HNO}_{3}$ to $\mathrm{pH} \approx 1$. Water samples were also collected in special gas flasks to preserve the dissolved oxygen content. In the laboratory, the dissolved oxygen was extracted from the flasks and measured by mass spectrometry. A major portion of the water sample was evaporated at 40-60 ${ }^{\circ} \mathrm{C}$ for pre-concentration. Standard ion-exchange chromatography was used to separate and purify the $U$ and thorium fractions in the groundwater [24]. Uranium and thorium concentrations were determined from filtered $0.45 \mu \mathrm{m}$ groundwater using high-resolution inductively coupled plasma mass spectrometry (HR-ICP-MS) with a Thermo ELEMENT II model (Thermo Fisher Scientific Inc., Waltham, MA, USA) at the State Key Laboratory of Mineral Deposit Research, Nanjing University. Analytical uncertainties were estimated by replicate analysis of the samples and were $0.03 \%$ and $3.5 \%$ for $U$ and Th concentrations, respectively. Uranium decay-series nuclides ${ }^{234} \mathrm{U},{ }^{238} \mathrm{U}$, and ${ }^{230} \mathrm{Th}$ from the water samples were measured using high-resolution alpha spectrometry at the Atomic Energy Institute of China, with a conservative analytical error within $\pm 10 \%$. The reliability of ${ }^{234} \mathrm{U} /{ }^{238} \mathrm{U}$ and ${ }^{230} \mathrm{Th} /{ }^{232} \mathrm{Th}$ ratios was checked by analyzing U NBS960 and ThS1 standard solutions, respectively. Analytical uncertainties were estimated by replicate analysis of the samples and were $1.1 \%$ for ${ }^{234} \mathrm{U} /{ }^{238} \mathrm{U}$ ratios. Alpha activity ratios ${ }^{234} \mathrm{U} /{ }^{238} \mathrm{U},{ }^{230} \mathrm{Th} /{ }^{238} \mathrm{U},{ }^{230} \mathrm{Th} /{ }^{234} \mathrm{U}$, and ${ }^{226} \mathrm{Ra} /{ }^{230} \mathrm{Th}$ of each water sample were calculated using the decay constants listed in Faure and Mensing [25].

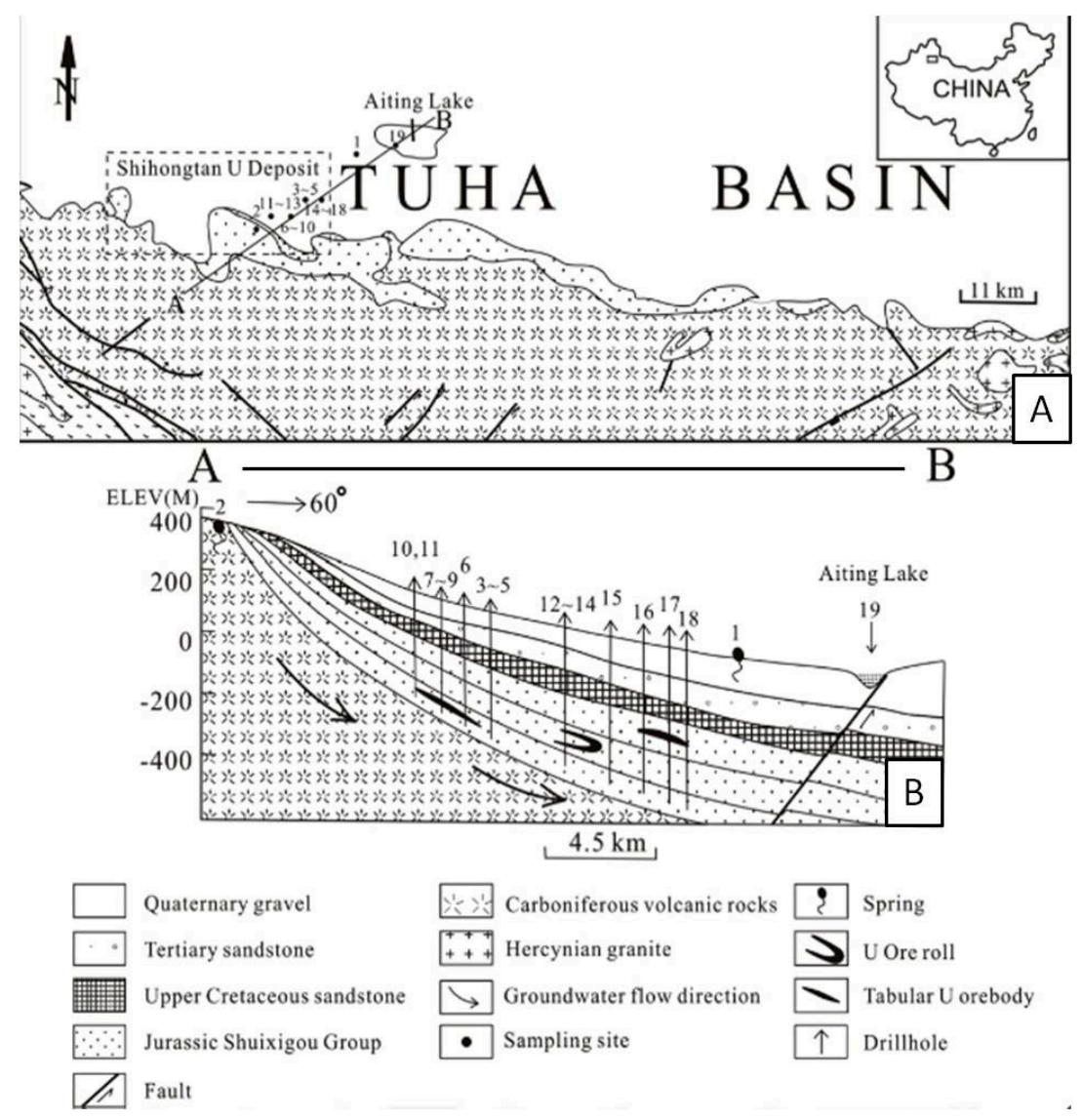

Figure 1. Simplified maps showing (A) the regional geological setting; and (B) the sample locations in hydrological cross-section of the Shuixigou-Group aquifer from the Shihongtan U ore district. From Min et al. [22]. 
Table 1. Concentration and activity ratio of U-series isotopes in the waters collected from the Shihongtan U ore district flow system.

\begin{tabular}{|c|c|c|c|c|c|c|c|c|c|c|c|c|c|}
\hline $\begin{array}{c}\text { Sample } \\
\text { No. }\end{array}$ & $\begin{array}{c}\text { Sample } \\
\text { Type }\end{array}$ & $\begin{array}{l}\text { Depth } \\
\text { (m) }\end{array}$ & $\mathrm{pH}$ & $\begin{array}{c}\text { Eh } \\
(\mathrm{mV})\end{array}$ & $\begin{array}{c}\mathrm{O}_{2} \\
(\mathrm{mg} / \mathrm{L})\end{array}$ & $\underset{(\mu \mathrm{g} / \mathrm{L})}{\mathrm{U}}$ & $\begin{array}{c}{ }^{238} \mathrm{U} \\
(\mathrm{Bq} / \mathrm{L})\end{array}$ & $\begin{array}{c}{ }^{234} \mathrm{U} \\
(\mathrm{Bq} / \mathrm{L})\end{array}$ & $\begin{array}{l}{ }^{230} \mathrm{Th} \\
(\mathrm{Bq} / \mathrm{L})\end{array}$ & ${ }^{234} U /{ }^{238} U$ & ${ }^{230} \mathrm{Th} /{ }^{234} \mathrm{U}$ & ${ }^{230} \mathrm{Th} /{ }^{238} \mathrm{U}$ & ${ }^{234} \mathbf{U}_{\mathrm{e}}$ \\
\hline 1 & Spring & surface & 7.0 & 413 & 6.0 & 0.13 & 0.10 & 0.15 & 0.10 & 1.50 & 0.67 & 1.00 & 0 \\
\hline 2 & Spring & surface & 8.0 & 456 & 6.5 & 0.11 & 1.40 & 2.10 & 0.80 & 1.50 & 0.38 & 0.57 & 0.06 \\
\hline 3 & Zk3w4 & 135 & 6.7 & 121 & 2.4 & 13.74 & 5.00 & 6.20 & 2.60 & 1.24 & 0.42 & 0.52 & 3.30 \\
\hline 4 & Zk3w4 & 140 & 6.7 & 124 & 2.2 & 55.49 & 9.70 & 9.50 & 4.30 & 0.98 & 0.45 & 0.44 & -1.11 \\
\hline 5 & Zk3w4 & 147 & 6.8 & 125 & 1.8 & 162.00 & 16.70 & 18.00 & 5.70 & 1.08 & 0.32 & 0.34 & 13.00 \\
\hline 6 & Zk5w1 & 70 & 6.5 & -26 & 2.0 & 0.21 & 129.30 & 226.50 & 78.80 & 1.75 & 0.35 & 0.61 & 0.16 \\
\hline 7 & Zk5w3 & 155 & 7.5 & -29 & 1.0 & 0.20 & 64.00 & 106.80 & 40.30 & 1.67 & 0.38 & 0.63 & 0.13 \\
\hline 8 & Zk5w3 & 165 & 7.2 & -29 & 0.9 & 0.21 & 31.80 & 51.20 & 18.40 & 1.61 & 0.36 & 0.58 & 0.13 \\
\hline 9 & Zk5w3 & 175 & 7.5 & -29 & 0.8 & 0.27 & 13.80 & 22.10 & 6.00 & 1.60 & 0.27 & 0.43 & 0.16 \\
\hline 10 & Zk9w5g & 305 & 7.3 & -32 & 0.2 & 0.01 & 0.30 & 0.40 & 0.20 & 1.33 & 0.50 & 0.67 & 0.01 \\
\hline 11 & Zk5w5g & 325 & 7.5 & -32 & 0.2 & 0.02 & 0.30 & 0.30 & 0.10 & 1.00 & 0.33 & 0.33 & 0 \\
\hline 12 & $\mathrm{Zk9w5}$ & 305 & 7.3 & -31 & 0.2 & 0.01 & 0.20 & 0.20 & 0.50 & 1.00 & 2.50 & 2.50 & 0 \\
\hline 13 & Zk9w5 & 325 & 7.3 & -28 & 0.2 & 0.41 & 2.20 & 2.50 & 1.00 & 1.14 & 0.40 & 0.45 & 0.90 \\
\hline 14 & Zk9w5 & 345 & 7.3 & -33 & 0.4 & 0.88 & 2.00 & 3.50 & 1.20 & 1.75 & 0.34 & 0.60 & 0.66 \\
\hline 15 & Zk7w2 & 30 & 7.9 & 286 & 1.2 & 8.30 & 8.80 & 10.50 & 4.20 & 1.19 & 0.40 & 0.48 & 1.58 \\
\hline 16 & Zk5-3 & 2 & 7.9 & 430 & 2.5 & 3.70 & 8.00 & 11.80 & 4.40 & 1.48 & 0.37 & 0.55 & 1.78 \\
\hline 17 & Zk7-3 & 2 & 7.6 & 124 & 5.0 & 17.68 & 8.70 & 12.30 & 4.80 & 1.41 & 0.39 & 0.55 & 7.25 \\
\hline 18 & Zk2-1 & 2 & 6.8 & 143 & 4.4 & 6.10 & 1.40 & 4.00 & 1.30 & 2.86 & 0.33 & 0.93 & 0.19 \\
\hline 19 & $\begin{array}{l}\text { Aiting } \\
\text { Lake }\end{array}$ & surface & 7.4 & 329 & 6.3 & 3.71 & 3.10 & 3.40 & 1.50 & 1.10 & 0.44 & 0.48 & 0.37 \\
\hline
\end{tabular}

Note: Sampling sites are shown in Figure 1. Zk3w4, Zk5w1, Zk5w3, Zk9w5g, Zk9w5, Zk7w2, Zk5-3, Zk7-3 and Zk2-1 are borehole codes. 
All designations of radioisotopes in this report are in terms of alpha activities, and all isotope ratios are in terms of alpha activity ratios (AR). The critical ARs are those of the shorter lived daughters relative to longer lived parents. Deviation of such ratios from 1.0 is termed disequilibrium and indicates that leaching or deposition has occurred within the system during a time frame determined by the daughter half-life. On the other hand, ARs equal to 1.0 indicate a lack of such disruptions for the time required for decay to erase the disequilibria. Given the conservative analytical uncertainty of $10 \%$, the measurable equilibration times for each of the daughters are about four half-lives: 1.0 Ma for ${ }^{234} \mathrm{U}$, $300 \mathrm{ka}$ for ${ }^{230} \mathrm{Th}$, and $6 \mathrm{ka}$ for ${ }^{226} \mathrm{Ra}$.

\section{Results and Discussion}

\subsection{Uranium Concentrations}

All analytical data are presented in Table 1 . The groundwater at a depth greater than $300 \mathrm{~m}$ is characterized by $\mathrm{Eh}<0 \mathrm{mV}$ and $\mathrm{pH}=7.3-7.5$. Some groundwaters (samples $3-5$ and $15-18$ ) collected from the oxidizing subzone aquifer have $U$ enrichment, ranging from 0.21 to $162.0 \mu \mathrm{g} / \mathrm{L}$, and an average of $38.14 \mu \mathrm{g} / \mathrm{L}$ (equivalent to ppb; Table 1). The $\mathrm{U}$ concentrations are obviously higher than that in unmineralized areas where $\mathrm{U}$ concentrations of the groundwaters are typically less than and close to $10 \mu \mathrm{g} / \mathrm{L}[22,26]$. Variations in $\mathrm{U}$ concentration of the groundwater are more dependent on dissolved oxygen concentration $\left(\mathrm{O}_{2}\right)$ and oxidation-reduction potential (Eh) of the waters (Figure 2). The solubility of $U$ in the groundwaters is very sensitive to changes in redox conditions. At the reducing barrier, the $U$ concentration becomes greatly reduced as water flows into the oxygen-depleted front; the $U$ is effectively removed from the water (Table 1 ). The $U$ concentration of the groundwaters from the reducing subzone aquifer (samples 10-14) in the Shihongtan ore district is typically lower than $1.00 \mu \mathrm{g} / \mathrm{L}(0.01-0.88 \mu \mathrm{g} / \mathrm{L})$, with an average of $0.27 \mu \mathrm{g} / \mathrm{L}$. However, the U concentration in the groundwaters increases toward the oxidizing subzone aquifer (samples 3-5 and 15-18) where values greater than $6.00 \mu \mathrm{g} / \mathrm{L}$ are common. The highest $\mathrm{U}$ concentrations (162.00 $\mu \mathrm{g} / \mathrm{L}$; sample 5) are likely to be due to the accumulation of $U$ in the groundwater along its flow path as it continues to interact with uraniferous rocks.
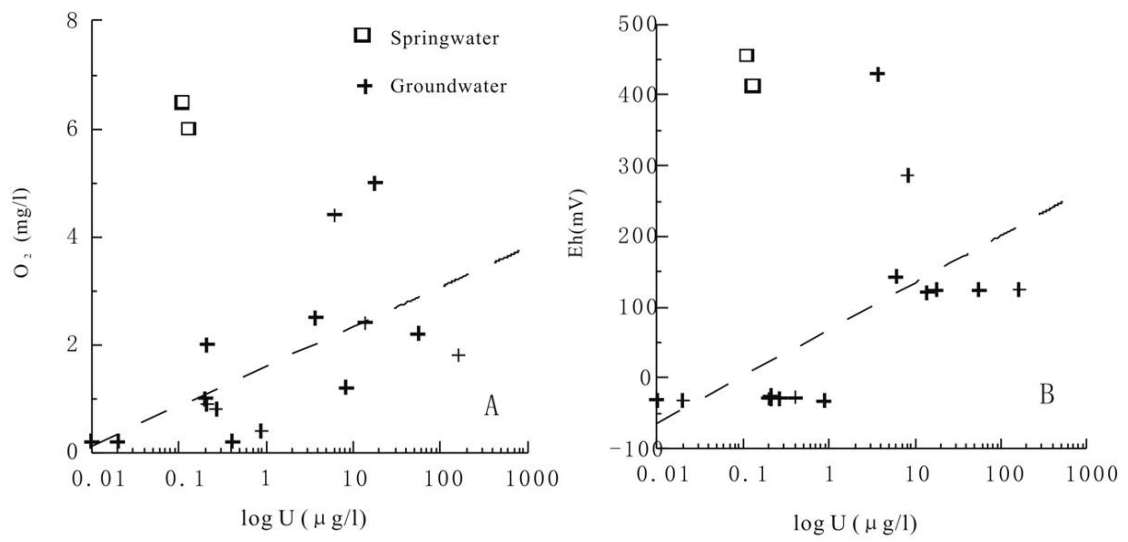

Figure 2. A plot of (A) $U$ and oxygen concentrations $\left(\mathrm{O}_{2}\right)$; and (B) $U$ concentrations and Eh values for waters from the Shihongtan $\mathrm{U}$ ore district. Data from Table 1.

Dissolved oxygen concentrations $\left(\mathrm{O}_{2}\right)$ and Eh levels reveal that a reducing front is present down dip in the confined portions of the aquifer (Table 1). The dissolved oxygen concentrations in the groundwaters from deep boreholes (more than $155 \mathrm{~m}$ ) are low $(0.2-1.0 \mathrm{mg} / \mathrm{L}$ ), and waters are anoxic at depth. Near-surface waters from springs and lakes have dissolved oxygen concentrations above saturation, ranging from 6.0 to $6.5 \mathrm{mg} / \mathrm{L}$, showing dissolved oxygen-enrichment. Elevated dissolved oxygen concentrations $(1.2-5.0 \mathrm{mg} / \mathrm{L}$ ) also occur in the samples from shallow boreholes (less than $135 \mathrm{~m})$. 
Elevated $U$ concentrations $(3.71 \mu \mathrm{g} / \mathrm{L})$ are also present in the lake water (sample 19). These elevated levels of $U$ may be due to increased $U$ levels in groundwater from drilling and mining activity in the Shihongtan ore district or they could be from weathering of the uraniferous sandstone and volcanic rocks. The U concentration of Spring 2 water $(0.11 \mu \mathrm{g} / \mathrm{L})$ is likely caused by the water cycling through U-rich volcanic rocks. Spring 1 water originates from the confined upper portions of the aquifer, mainly contains meteoric water, and has lower U concentrations $(0.13 \mu \mathrm{g} / \mathrm{L})$.

\subsection{Activity Concentrations of U-Series Radionuclide}

The ${ }^{238} \mathrm{U}$ activity concentrations of waters from the ore district can be divided into two groups: one ranges from 0.10 to $2.20 \mathrm{~Bq} / \mathrm{L}$, and the other ranges from 3.10 to $129.30 \mathrm{~Bq} / \mathrm{L}$, typical of oxygenated waters [26]. The observed ${ }^{238} \mathrm{U}$ activity concentrations suggest relatively high mobility of $\mathrm{U}$ isotopes due to the formation of uranyl-anion complexes such as $\left(\mathrm{UO}_{2}\right)\left(\mathrm{CO}_{3}\right)_{3}{ }^{4-}$ under oxygenated conditions [27]. Main anion species in the groundwaters are: $\mathrm{Cl}^{-}\left(2623.5-5442.2 \mathrm{mg} / \mathrm{L}^{-}, \mathrm{SO}_{4}{ }^{2-}\right.$ (1913.5-2405.3 mg/L) and $\mathrm{HCO}_{3}-(36.6-769.0 \mathrm{mg} / \mathrm{L})$ [22]. Uranyl-carbonate complexes are the most important U-complexes in the oxygenated, carbonate-rich groundwaters [27]. The wide range of ${ }^{238} \mathrm{U}$ in the aquifer waters is a reflection of diverse vadose zone inputs $[17,28]$.

The ${ }^{234} \mathrm{U}$ activity concentration of the waters varies from 0.15 to $226.50 \mathrm{~Bq} / \mathrm{L}$. Significant radioactive disequilibria exist between $U$ and its daughter nuclides. For instance, the ${ }^{230} \mathrm{Th} /{ }^{234} \mathrm{U}$ and ${ }^{230} \mathrm{Th} /{ }^{238} \mathrm{U}$ ARs range from 0.27 (sample 9) to 2.50 (sample 12) and from 0.33 (sample 11) to 2.50 (sample 12), respectively. The estimated solubility of Th in pure water is low, only $10 \mathrm{pg} / \mathrm{kg}$ [29], whereas Th solubility in natural waters can increase greatly up to $\mathrm{pH} 8$ by complexing with carbonate and bicarbonate species [30]. However, at $\mathrm{pH}$ values above 8 , Th-hydroxyl species dominate over Th-carbonate species. The measured ${ }^{230} \mathrm{Th}$ activity concentrations in waters are near the solubility limit for thorianite $\left(\mathrm{ThO}_{2}\right)$ with some enhancement presumably due to the presence of ligands. Furthermore, preferential ${ }^{234} \mathrm{U}$ removal $\left({ }^{234} \mathrm{U} /{ }^{238} \mathrm{U} \mathrm{AR}<1\right)$ was observed.

The ${ }^{238} \mathrm{U},{ }^{234} \mathrm{U}$ and ${ }^{230} \mathrm{Th}$ activity concentrations of the groundwater samples 3-9, 15-18 are all high, especially for the groundwater samples 6, ,7 and 9, with activity concentrations between 13.80 and $129.30 \mathrm{~Bq} / \mathrm{L}$ for ${ }^{238} \mathrm{U}$, between 22.10 and $226.50 \mathrm{~Bq} / \mathrm{L}$ for ${ }^{234} \mathrm{U}$, and between 6.00 and 78.80 for ${ }^{230} \mathrm{Th}$, respectively (Table 1 ). Moreover, the activity concentrations of the U-series radionuclide for almost all water samples show that ${ }^{234} \mathrm{U}>{ }^{238} \mathrm{U}>{ }^{230} \mathrm{Th}$, due to differences in groundwater input rates, as well as in removal rates.

\subsection{Activity Ratios of U-Series Radionuclide}

The use of ${ }^{230} \mathrm{Th} /{ }^{238} \mathrm{U}$ to recognize accumulation or leaching of $U$ at an ore site is straight-forward because Th is immobile and disequilibrium can be effected only by movement of $U$, but interpretation of ${ }^{234} \mathrm{U} /{ }^{238} \mathrm{U}$ is ambiguous since the ratio at the sampling site can be produced by secondary $\mathrm{U}$ mineral precipitation from the ground water after being produced up-flow. Given such complicating possibilities, we rely here on the plausible scenarios described by Thiel et al. [31] and depicted in Figure 3.

The ${ }^{234} \mathrm{U} /{ }^{238} \mathrm{U}$ and ${ }^{230} \mathrm{Th} /{ }^{234} \mathrm{U}$ ARs for the majority of water samples display values out of equilibrium $(>1.10$ or $<0.90)$. The activity ratios of the waters are characterized by ${ }^{234} \mathrm{U} /{ }^{238} \mathrm{U} A R \geqslant 1$, ${ }^{230} \mathrm{Th} /{ }^{234} \mathrm{U}$ and ${ }^{230} \mathrm{Th} /{ }^{238} \mathrm{U}$ ARs $<1$ except sample $11\left({ }^{230} \mathrm{Th} /{ }^{234} \mathrm{U} \mathrm{AR}={ }^{230} \mathrm{Th} /{ }^{238} \mathrm{U} \mathrm{AR}=2.50\right)$. The ${ }^{230} \mathrm{Th} /{ }^{234} \mathrm{U}$ activity ratios are all rather high. This indicates relatively recent deposition of $\mathrm{U}$ from water with ${ }^{234} U /{ }^{238} U$ AR $>1$ (Figure 3). This result is similar to the cases studied by [13,32,33]. Suksi et al. [13] reported fracture calcites from the groundwaters with ${ }^{230} \mathrm{Th} /{ }^{234} \mathrm{U} \mathrm{AR}=3.22$ in Almottu, Finland. Toulhoat et al. [34] proposed a classification of waters based on two parameters, $\mathrm{U}$ concentration and ${ }^{234} \mathrm{U} /{ }^{238} \mathrm{U}$ AR. High ${ }^{234} \mathrm{U} /{ }^{238} \mathrm{U}$ AR $(>2.0)$ can be due to a higher than normal ratio of leachable $\mathrm{U}$ in aquifer or amorphous uraninite, enhancing $\alpha$-recoil. A ${ }^{234} U /{ }^{238} \mathrm{U}$ AR less than 1 implies intense dissolution. 
Groundwater ${ }^{234} \mathrm{U} /{ }^{238} \mathrm{U}$ AR ranges from 0.98 to 2.86 (median value for all samples of 1.43 ) with substantial overlap between values from different samples. The highest value $\left({ }^{234} U /{ }^{238} U\right.$ AR of 2.86$)$ is for sample 18 from a near-surface aquifer (borehole Zk2-1). The data presented in Table 1 show that ${ }^{234} \mathrm{U} /{ }^{238} \mathrm{U},{ }^{230} \mathrm{Th} /{ }^{234} \mathrm{U}$, and ${ }^{230} \mathrm{Th} /{ }^{238} \mathrm{U}$ ARs for most of the water samples are obvious deviations from secular equilibrium and are enriched in ${ }^{234} U$ (Figure 3). Although ${ }^{234} U /{ }^{238} U$ AR of the water samples $4,11,12$, and 19 are near unity or show very little deviation from secular equilibrium (0.98-1.10), their ${ }^{230} \mathrm{Th} /{ }^{234} \mathrm{U}$ and ${ }^{230} \mathrm{Th} /{ }^{238} \mathrm{U}$ ARs show obvious deviations from secular equilibrium, ranging from 0.27 (sample 9) to 2.50 (sample 12) and from 0.33 (sample 11) to 2.50 (sample 12), respectively. The high value of ${ }^{234} \mathrm{U} /{ }^{238} \mathrm{U}$ AR and low value of ${ }^{230} \mathrm{Th} /{ }^{234} \mathrm{U}$ and ${ }^{230} \mathrm{Th} /{ }^{238} \mathrm{U}$ ARs can only be generated by enhanced ${ }^{234} \mathrm{U}$ gain and an inherited ${ }^{230} \mathrm{Th}$ during weathering $[18,25]$.

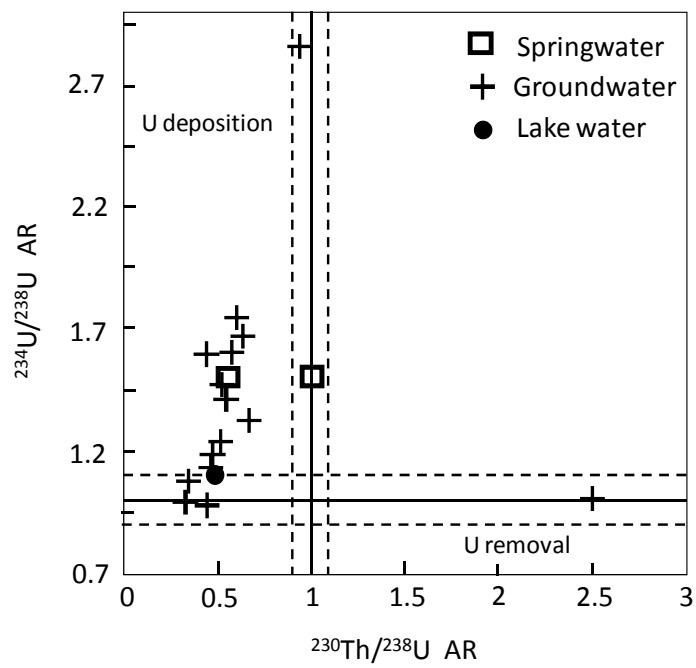

Figure 3. Thiel diagram of $U$ decay series for waters from the Shihongtan $U$ ore district. Most samples plot in the $U$ deposition region. Solid lines represent secular equilibrium and the dashed lines define error limits. Data from Table 1.

\subsection{Fluid Mixing}

Figure 4 shows the relationship between the ${ }^{234} U /{ }^{238} U$ AR and $U$ concentration from water samples. All samples with a low $U$ concentration show disequilibria with high ${ }^{234} U /{ }^{238} U$ AR values $(>1-2)$. The ${ }^{234} U /{ }^{238} U$ AR generally increases with decreasing $U$ concentrations (Table 1, Figure 3). $\mathrm{U}$ can be precipitated when the groundwaters become anoxic since reduced $\mathrm{U}^{4+}$ is much more insoluble. Therefore, the $U$ concentration for some groundwaters (samples 6-14) is low and the ${ }^{234} U /{ }^{238} U$ AR is high due to efficient recoil from precipitated uraninite [26,35]. The high ${ }^{234} U /{ }^{238} U$ AR values of the waters reflect preferential dissolution of ${ }^{234} \mathrm{U}$ relative to ${ }^{238} \mathrm{U}$ from rocks due to the $\alpha$-recoil effect during the $\alpha$-decay of ${ }^{238} \mathrm{U}$ to ${ }^{234} \mathrm{Th}[5,36,37]$. However, dissolution of aquifer rocks decreases the ${ }^{234} \mathrm{U} /{ }^{238} \mathrm{U}$ AR in groundwater because this ratio in rocks is close to unity. Our data show roughly a linear correlation between ${ }^{234} U /{ }^{238} U$ AR and the inverse of the $U$ concentration (Figure 4), suggesting that the mixing of at least three components, which are (1) low $U$ concentration $(0.01 \sim 0.02)$ with $A R=1$; (2) high $U$ concentration with $A R=1$; and (3) low $U$ concentration with $A R>1$, may occur in the aquifer. It is supported by the fact that $U$ ore bodies mainly have a tabular shape with a thickness ranging from 3 to $18 \mathrm{~m}$ and length of $\sim 200 \mathrm{~m}$. Their attitudes are sub-parallel to bedding (Figure 1B). The tabular $\mathrm{U}$ ore bodies were formed from mixing between a relatively stagnant saline fluid and a rapid flowing U-bearing meteoric water [38-40]. Dabous and Osmond [40] reported that waters from the sandstone Nubian Aquifer in Egypt exhibit broad correlations between ${ }^{234} U /{ }^{238} U$ AR and $1 / U_{\text {con., }}$. consistent with mixing between recharging and aquifer waters with distinct ${ }^{234} U /{ }^{238} U$ AR as well as ${ }^{238} \mathrm{U}$ and excess ${ }^{234} \mathrm{U}$ concentrations. 
Therefore older $U$ ore bodies, which are dissolved by oxidizing or saline groundwaters in the Shihongtan aquifer could be the source of $U$ in the high-U groundwaters (samples 4-9, 15-17) is great $(0.20-162.00 \mu \mathrm{g} / \mathrm{L}$, mean $27.56 \mu \mathrm{g} / \mathrm{L})$, whereas some groundwaters may be relatively depleted in $\mathrm{U}$ (samples 10-14; 0.01-0.88 $\mu \mathrm{g} / \mathrm{L}$, mean $0.26 \mu \mathrm{g} / \mathrm{L}$ ) because $\mathrm{U}$ has precipitated along a fixed front.

The ${ }^{234} \mathrm{U}$-excess $\left({ }^{234} \mathrm{Ue}\right)$, which is defined as [41]:

$$
{ }^{234} \mathrm{Ue}=\left[{ }^{234} \mathrm{U} /{ }^{238} \mathrm{U}-1\right] \times \mathrm{U}_{\mathrm{con}}
$$

is released by recoil from host minerals of ${ }^{234} \mathrm{Th}$, followed by decay to ${ }^{234} \mathrm{~Pa}$ and then to ${ }^{234} \mathrm{U}$. In our case, the ${ }^{234}$ Ue increases approximately with the increase in U concentration (Figure 5). This excess can also be interpreted to be due to higher mobility of ${ }^{234} \mathrm{U}$, which more readily forms the soluble $\left(\mathrm{UO}_{2}\right)^{2+}$ ion in comparison with ${ }^{238} \mathrm{U}$, most of which remains in the insoluble $4^{+}$state $[11,42]$. Where removal processes are not fractionating, the ratio of ${ }^{234} \mathrm{Th}$ recoil release rate to weathering rate will be retained in the groundwater. In this case, the measured ratio of the excess ${ }^{234} \mathrm{U}$ to ${ }^{238} \mathrm{U}$ (that is, $\left.\left({ }^{234} \mathrm{U} /{ }^{238} \mathrm{U}\right)_{\mathrm{w}}-1\right)$ is equal to the ratio of recoil supply to weathering [17].

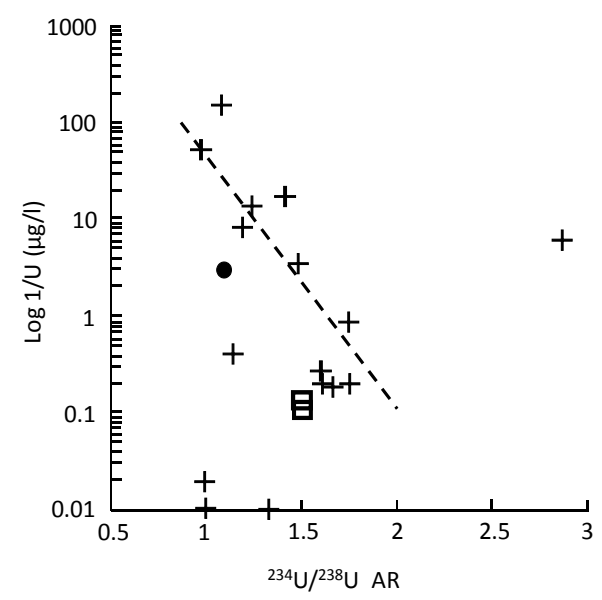

Figure 4. ${ }^{234} \mathrm{U} /{ }^{238} \mathrm{U}$ AR versus $\log 1 / \mathrm{U}$ concentrations for the spring 1 waters (samples 1 ), groundwaters (samples 2-18) and lake waters (sample 19) from the Shihongtan U ore district flow system. Data from Table 1. Symbols as in Figure 3.

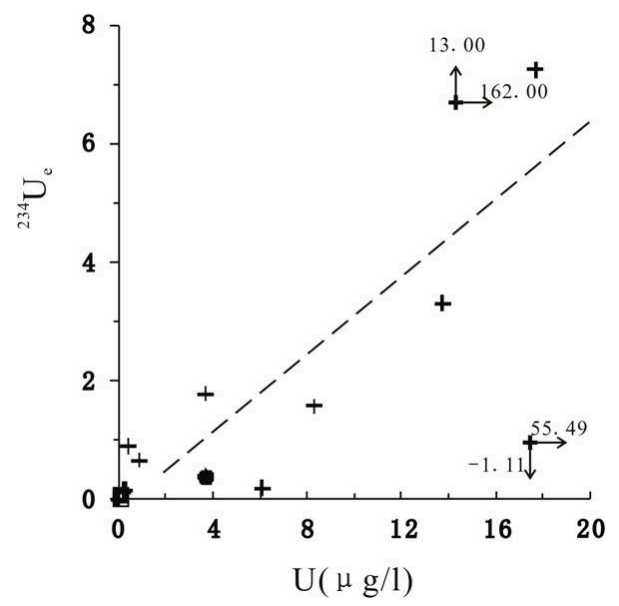

Figure 5. ${ }^{234} \mathrm{U}$ excess $\left({ }^{234} \mathrm{Ue}\right)$ as a function of $U$ concentration in parts per billion, by weight, for the spring 1 waters (samples 1 ), groundwaters (samples 2-18) and lake water (sample 19) from the Shihongtan U ore district flow system. Drawn from the data in Table 1. Symbols as in Figure 3. Arrows indicate maximum and minimum values for data points that plot off scale. 


\section{Conclusions}

Based on deviations from secular equilibrium $(0.27-2.86)$ of ${ }^{234} \mathrm{U} /{ }^{238} \mathrm{U},{ }^{230} \mathrm{Th} /{ }^{234} \mathrm{U}$, and ${ }^{230} \mathrm{Th} /{ }^{238} \mathrm{U}$ ARs and rather high $\mathrm{U}$ concentrations in present day groundwaters, $\mathrm{U}$ could locally be precipitating within sandstone aquifers of the Shihongtan ore district where appropriate redox conditions are created. U-series disequilibria, therefore, can provide an important tool for tracing groundwaters from different aquifer conditions. However, clear interpretations of activity ratios of the U-series isotope and quantification of the responsible processes, as pointed out by [36], remain difficult.

Acknowledgments: We are grateful to the Northwest Institute of Uranium Geology (NWIUG), China National Nuclear Corporation, who provided help in sampling water and with partial unpublished data. The work was supported by the National Natural Science Foundation of China (Grant No. 40573022), the Base Research Foundation from the Education Ministry of China (Grant No. 20060284025), the Analysis Foundation of Nanjing University and partially supported by the special research foundation from the Bureau of Geology, China National Nuclear Corporation. This work also benefited from financial contribution by the Natural Sciences and Engineering Research Council of Canada (NSERC) via a Discovery grant and the Canada Research Chair program.

Author Contributions: All of the authors were involved in the laboratory work, sample characterization, writing and revising of all parts of the manuscript.

Conflicts of Interest: The authors declare no conflict of interest.

\section{References}

1. Osmond, J.K.; Cowart, J.B. The theory and uses of natural uranium isotopic variations in hydrology. At. Energy Rev. 1976, 14, 621-679.

2. Lozano, J.C.; Rodríguez, P.B.; Tomé, F.V. Distribution of long-lived radionuclides of the ${ }^{238} \mathrm{U}$ series in the sediments of a small river in a uranium mineralized region of Spain. J. Environ. Radioact. 2002, 63, 153-171. [CrossRef]

3. Paces, J.B.; Ludwig, K.R.; Peterman, Z.E.; Neymark, L.A. ${ }^{234} \mathrm{U} /{ }^{238} \mathrm{U}$ evidence for local recharge and patterns of groundwater flow in the vicinity of Yucca Mountain, Nevada. Appl. Geochem. 2002, 17, 751-779. [CrossRef]

4. Osmond, J.K.; Dabous, A.A. Timing and intensity of groundwater movement during Egyptian Sahara pluvial periods by U-series analysis of secondary $U$ in ores and carbonates. Quat. Res. 2004, 61, 85-94. [CrossRef]

5. Payne, T.E.; Airey, P.L. Radionuclide migration at the Koongarra uranium deposit, Northern Australia-Lessons from the Alligator Rivers analogue project. Phys. Chem. Earth 2006, 31, 572-586. [CrossRef]

6. Allard, T.; Calas, G.; Ildefonse, P. Reconstruction of past U migration in a sedimentary deposit (Coutras, France): Implications for a radwaste repository. Chem. Geol. 2007, 239, 50-63. [CrossRef]

7. Porcelli, D.; Swarzenski, P.W. The behavior of U- and Th-series nuclides in groundwater. Rev. Mineral. Geochem. 2003, 52, 317-361. [CrossRef]

8. Sujo, L.C.; Cabrera, M.E.M.; Villalba, L.; Villalobos, M.R.; Moye, E.T.; García León, M.G.; García-Tenorio, R.; García, F.M.; Peraza, E.F.H.; Aroche, D.S. Uranium-238 and thorium-232 series concentrations in soil, radon-222 indoor and drinking water concentrations and dose assessment in the city of Aldama, Chihuahua, Mexico. J. Environ. Radioact. 2004, 77, 205-219. [CrossRef] [PubMed]

9. Andrews, J.N.; Kay, R.L.F. The $U$ contents and ${ }^{234} U /{ }^{238} U$ activity ratios of dissolved uranium in groundwaters from some Triassic sandstones in England. Isot. Geosci. 1983, 1, 101-117. [CrossRef]

10. Mallick, R.; Frank, N. A new technique for precise uranium-series dating of travertine micro-samples. Geochim. Cosmochim. Acta 2002, 66, 4261-4272. [CrossRef]

11. Abdul-Hadi, A.; Alhassanieh, O.; Ghafar, M. Diaequilibrium of uranium isotopes in some Syrian groundwater. Appl. Radiat. Isot. 2001, 55, 109-113. [CrossRef]

12. Thompson, W.G.; Spiegelman, M.W.; Goldstein, S.L.; Speed, R.C. An open-system model for U-series age determinations of fossil corals. Earth Planet. Sci. Lett. 2003, 210, 365-381. [CrossRef]

13. Suksi, J.; Rasilainen, J.K.; Casanova, J.; Ruskeeniemi, T.; Blomqvist, R.; Smellie, J.A.T. U-series disequilibria in a groundwater flow route as an indicator of uranium migration processes. J. Contam. Hydrol. 2001, 47, 187-196. [CrossRef] 
14. Kokfelt, T.F.; Lundstrom, C.; Hoernle, K.; Hauff, F.; Werner, R. Plume-ridge interaction studied at the Galápagos spreading center: Evidence from ${ }^{226} \mathrm{Ra}^{230} \mathrm{Th}^{238} \mathrm{U}$ and ${ }^{231} \mathrm{~Pa}-{ }^{235} \mathrm{U}$ isotopic disequilibria. Earth Planet. Sci. Lett. 2005, 234, 165-187. [CrossRef]

15. Vogel, J.C.; Talma, A.S.; Heaton, T.H.E.; Kronfeld, J. Evaluating the rate of migration of a uranium deposition front within the Uitenhage Aquifer. J. Geochem. Explor. 1999, 66, 269-276. [CrossRef]

16. Hakam, O.K.; Choukri, A.; Moutia, Z.; Chouak, A.; Cherkaoui, R.; Reyss, J.-L.; Lferde, M. Uranium and radium in groundwater and surface water samples in Morocco. Radiat. Phys. Chem. 2001, 61, 653-654. [CrossRef]

17. Tricca, A.; Wasserburg, G.J.; Porcelli, D.; Baskaran, M. The transport of U- and Th-series nuclides in a sandy unconfined aquifer. Geochim. Cosmochim. Acta 2001, 65, 1187-1210. [CrossRef]

18. Reynolds, B.C.; Wasserburg, G.J.; Baskaran, M. The transport of U- and Th-series nuclides in sandy confined aquifers. Geochim. Cosmochim. Acta 2003, 67, 1955-1972. [CrossRef]

19. Suksi, J.; Rasilainen, K.; Pitkänen, P. Variations in ${ }^{234} \mathrm{U} /{ }^{238} \mathrm{U}$ activity ratios in groundwater-A key to flow system characterisation? Phys. Chem. Earth 2006, 31, 556-571. [CrossRef]

20. Li, B.; Li, Z. Geological and geochemical characteristics of section first to be mined, Shihongtan uranium deposit, Tuha basin. Uranium Geol. 2003, 19, 193-202. (In Chinese).

21. Min, M.Z.; Chen, J.; Wang, J.P.; Wei, G.H.; Fayek, M. Mineral paragenetic associations and textural patterns in the sandstone-hosted roll-type uranium deposits, NW China. Ore Geol. Rev. 2005, 26, 51-69. [CrossRef]

22. Min, M.Z.; Peng, X.J.; Qiao, H.M.; Chen, J.; Grobe, M. Hydrochemistry and isotope composition of groundwaters from the Shihongtan sandstone-hosted uranium deposit, Xinjiang, NW China. J. Geochem. Explor. 2007, 93, 91-108. [CrossRef]

23. Min, M.Z.; Peng, X.J.; Wang, J.P.; Osmond, J.K. Uranium-series disequilibria as a means to study recent migration of uranium in a sandstone-hosted uranium deposit, NW China. Appl. Radiat. Isot. 2005, 63, 115-125. [CrossRef] [PubMed]

24. Gäfvert, T.; Ellmark, C.; Holm, E. Removal of radionuclides at a waterworks. J. Environ. Radioact. 2002, 63, 105-115. [CrossRef]

25. Faure, G.; Mensing, T.M. Isotopes: Principles and Applications, 3rd ed.; Wiley: Hoboken, NJ, USA, 2005 ; p. 528.

26. Osmond, J.K.; Cowart, J.B. Ground water. In Uranium-Series Disequilibrium: Applications to Earth, Marine and Environmental Sciences, 2nd ed.; Ivanovich, M., Harmon, R.S., Eds.; Clarendon Press: Oxford, UK, 1992; pp. 290-334.

27. Langmuir, D. Uranium-solution-mineral equilibria at low temperatures with applications to sedimentary ores deposits. Geochim. Cosmochim. Acta 1978, 42, 547-569. [CrossRef]

28. Cochran, J.K.; Feng, H.; Amiel, D.; Beck, A. Natural radionuclides as tracers of coastal biogeochemical processes. J. Geochem. Explor. 2006, 88, 376-379. [CrossRef]

29. Langmuir, D.; Herman, J.S. The mobility of thorium in natural waters at low temperatures. Geochim. Cosmochim. Acta 1980, 44, 1753-1766. [CrossRef]

30. Anderson, R.F.; Bacon, M.P.; Brewer, P.G. Elevated concentrations of actinides in Mono Lake. Science 1982, 216, 514-516. [CrossRef] [PubMed]

31. Thiel, K.; Vorwerk, R.; Saager, R.; Stupp, H.D. ${ }^{235} \mathrm{U}$ fission tracks and ${ }^{238} \mathrm{U}$-series disequilibria as a means to study recent mobilization of uranium in Archaean pyretic conglomerates. Earth Planet. Sci. Lett. 1983, 65, 249-262. [CrossRef]

32. Levinson, A.A.; Bland, C.J.; Dean, J.R. Uranium series disequilibrium in young surficial uranium deposits in southern British Columbia. Can. J. Earth Sci. 1984, 21, 559-566. [CrossRef]

33. Osmond, J.K.; Dabous, A.A.; Dawood, Y.H. U series age and origin of two secondary uranium deposits, central Eastern Desert, Egypt. Econ. Geol. 1999, 94, 273-280. [CrossRef]

34. Toulhoat, P.; Holliger, P.; Menes, J. Analyses of lead isotopes and U-series disequilibrium in groundwater and possible sources rocks in the west Morvan area. Uranium 1988, 4, 307-325.

35. Forte, M.; Rusconi, R.; Cazzaniga, M.T.; Sgorbati, G. The measurement of radioactivity in Italian drinking waters. Microchem. J. 2007, 85, 98-102. [CrossRef]

36. Bourdon, B.; Henderson, G.M.; Lundstrom, C.C.; Turner, S.P. Uranium-series Geochemistry. Rev. Mineral. Geochem. 2003, 52, 317-361. [CrossRef] 
37. Zhou, J.; Lundstrom, C.C.; Fouke, B.; Panno, S.; Hackley, K.; Curry, B. Geochemistry of speleothem records from southern Illinois: Development of $\left({ }^{234} U\right) /\left({ }^{238} U\right)$ as a proxy for paleoprecipitation. Chem. Geol. 2005, 221, 1-20. [CrossRef]

38. Northrop, H.R.; Goldhaber, A.B. Genesis of the tabular-type vanadium-uranium deposits of the Henry Basin, Utah. Econ. Geol. 1990, 85, 215-269. [CrossRef]

39. Luo, S.D.; Ku, T.L.; Roback, R.; Murrell, M.; Mcling, T.L. In-situ radionuclide transport and preferential groundwater flows at INEEL (Idaho): Decay-series disequilibrium studies. Geochim. Cosmochim. Acta 2000, 64, 867-881. [CrossRef]

40. Dabous, A.A.; Osmond, J.K. Uranium isotopic study of artesian and pluvial contributions to the Nubian Aquifer, Western Desert, Egypt. J. Hydrol. 2001, 243, 242-253. [CrossRef]

41. Cowart, J.B.; Osmond, J.K. The relationship of uranium isotopes to oxidation/reduction in the Edwards carbonate aquifer of Texas. Earth Planet. Sci. Lett. 1980, 48, 277-283. [CrossRef]

42. Pietruszka, A.J.; Rubin, K.H.; Garcia, M.O. ${ }^{226}$ Ra- $-{ }^{230} \mathrm{Th}^{-238} \mathrm{U}$ disequilibria of historical Kilauea lavas (1790-1982) and the dynamics of mantle melting within the Hawaiian plume. Earth Planet. Sci. Lett. 2001, 186, 15-31. [CrossRef]

(C) 2015 by the authors; licensee MDPI, Basel, Switzerland. This article is an open access article distributed under the terms and conditions of the Creative Commons by Attribution (CC-BY) license (http://creativecommons.org/licenses/by/4.0/). 